\title{
The Impact of Educational Trust Fund on Nigeria Tertiary Institutions: Ondo State as a Case Study
}

\author{
Dare Williams OMOTOYINBO PhD \\ Adekunle Ajasin University, Akungba Akoko, Ondo State, Nigeria
}

\begin{abstract}
The study examines impact of Education Trust Fund on Nigeria tertiary institutions by using Ondo State of Nigeria as a case study. Four tertiary institutions were sampled in Ondo state namely (Federal University of Technology, Akure (FUTA), Adekunle Ajasin University Akungba-Akoko (AAUA), Rufus Giwa Polytechnic Owo and Adeyemi College of Education, Ondo. A total sample of 200 were used for the study. Questionnaires were distributed among the students, teaching and non teaching staff in the same proportions, to gather data for the study Frequency counts and simple percentages were used to analyse the data. The result shows that Tertiary institutions in Ondo state have benefited greatly from the activities of the Educational Trust Fund (ETF) programmes in terms of training of staff, sponsorship attendance of conferences and infrastructural development programmes. Therefore, it is clear that the impact of Educational Trust Fund (ETF) has on Nigeria tertiary institutions particularly in Ondo state is paramount towards the achievements of better teaching and learning process. It is therefore recommended that Educational Trust Fund should make sure that they assign their projects to only contractors who are certified to be honest and competent. The monitoring team should be at work always to make sure that they evaluate the project at close interval
\end{abstract}

Keywords: Educational Trust fund, Tertiary Institutions, Projects, Impact, Evaluate the project

DOI: $10.7176 / \mathrm{JEP} / 10-6-04$

\section{Introduction}

Education can be described as a process of providing the necessary knowledge for guiding and assisting human beings towards a more rewarding and desired life as well as for the good of the society.

According to Amadi (2004), Education is an instrument for effecting national development as a form of production and reproduction of knowledge of people's way of life with the aim of preserving and maintaining the social structure that will be able to guarantee social order and changes in the society. Tertiary Education can be referred to as the education given to an individual after secondary school education in universities, polytechnics, colleges of education and those institutions offering corresponding courses at this level. Students are there equipped with skills and competence that they need to acquire and are awarded qualifying certificates required to get employment after their course of study.

In developed countries, government provides some resources to finance higher education, but, there is a continuous effort on the part of university administrators to mobilise and diversify resources to supplement what government provides. In advanced countries, there has been an upsurge in the demand for policy restructuring to reduce the over reliance on the central government to financing higher education. At the same time, there has been a gradual shift from the provision of free higher education in countries to a system of cost sharing where students themselves contribute towards their education.

However, the situation is quite different in most African countries especially in Nigeria where the introduction of cost-sharing has generated an incredible gap of inequalities between students from the rich and the poor homes, thus making higher education the preserve of the affluent segment of the society.

Tertiary education in Nigeria is bedevilled by some challenges which are invariably having great impact on the end products. Many papers have been written on this problem with little effects. Among the numerous problems according to Ahmed (2011), are the legacies of colonialism which had lingered and in some instances directed the thrust of tertiary education policy. Other problems identified by this scholar includes financing and funding the growth of private tertiary education institutions, academic freedom, quality and excellent governance, autonomy and other management challenges.

The most critical problem confronting tertiary institutions in Nigeria is funding. If this problem is solved, many others will be resolved or reduced. According to Nwangwu (2005), when education is not well funded, the foundation of such education are weak and consequently, the products of such education systems are generally weak intellectually. It is un-debatable that there is a reduction of the funds made available to each institution by government hence the quest for tertiary institutions to generate funds by any means including reduction of their staff salaries, unreasonable and unbearable increase in students' school fees.

The alternatives government source for financing tertiary institutions include, but are not restricted to the following: 


\section{Internally Generated Revenue (IGR)}

As a means of finding solution to the seemingly insurmountable problems in the nation's higher education, the Federal and some state government directed each university to generate at least Ten percent $(10 \%)$ of its total revenue.

\section{Tuition Fees:}

Higher Education in Nigeria tertiary institutions receive a reasonable percentage of their revenue through student's school fees. The part -time and pre-degree programmes claimed to be offered by higher institutions in Nigeria are mere profit-making ventures which invariably affect the graduates thereby produced. For example what is the percentage of those pre-degree students that pass JAMB and post JAMB exams? The answer will reveal some headshake and an unprintable page of hiss-igniting comments.

\section{Endowments Funds or Donations}

Many institutions of higher education in Nigeria establish endowment funds where rich citizens assist in the development of quality education and prominent citizens are encouraged to donate money and physical structures, held in their honour perpetually, to the institution. Some prominent figures (worthy or not) are awarded honorary degrees just as a bait to have access to their wealth.

\subsection{Grants}

Foreign grants have been received by Nigeria higher institutions in form of aids to support academic programmes and staff development. Some of the agencies that come to mind include Ford Foundation, World Health Organization (WHO), Carnegie Foundation, John D and Catherine T., Mac Arthur Foundations, among others. Some of these Foundations have been supporting Four (4) Universities in the key areas of staff development and ICT infrastructure in Nigeria since 2010 (Ogbogu, 2011)

\subsection{Private Contributions}

Big firms, companies and investors such as Chevron Julius Berger, Dangote etc make contributions in form of money, physical structures to the development of higher education in Nigeria. There are also organizations such as Lion's Club, Rotary Club, do donate books, buildings and even money to Nigeria institutions of learning. However, these various contributions could not meet the numerous needs of higher education in Nigeria. Emanating from this, other urgent interventions from government gave birth to the Education Trust Fund (ETF) now changed to Tertiary Education Trust Fund (TETF)

\section{History of Tertiary Education Trust Fund}

From 1980 and beyond, the decay of all tiers of education was monumental. Facilities have almost collapsed, teachers and lecturers' morale was at its lowest ebb, enabling environment for conducive teaching and learning was absent. The administration of President Ibrahim Babangida, mindful of the reality of the situation, took measures to arrest the rot. In December 1990, the Federal government constituted the Grey-Longe Commission to review the post independence Nigeria Higher Education after Lord Ashby's commission of 1959.

The Longe commission recommended among others the funding of higher education through ear-marked tax to be borne by companies operating in Nigeria. An implementation committee under the chairmanship of Professor Olu O. Akinkuogbe was constituted. Apart from implementing the recommendations of Grey Longe, an agreement was also signed between the Federal government and ASUU on the 3rd of September, 1992 on funding public higher institutions in Nigeria. In 1993, the Education Trust Fund Act No 7 of 1993 was promulgated alongside other education related decrees. The decree which imposed a $2 \%$ tax on the assessable profits of all companies in Nigeria brought a huge solution to the issue of funding, rehabilitating decaying infrastructure, restoring the lost glory of education and confidence in the system, as well as consolidate the gains of building the capacity of teachers and lecturers, teachers' development, prototype development etc. The TETF Act also mandated the fund to operate as an intervention fund to all levels of public education.

Today, the Education Trust Fund (TETF) has formed a major source of funding for teaching facilities, research conferences and staff training and development in Nigeria tertiary institutions. This paper is looking at such impacts of Education Trust Fund (ETF) now Tertiary Education Trust Fund (TETF) in the Federal University of Technology Akure (FUTA) Adekunle Ajasin University Akungba (AAUA) described as the best state university in Nigeria, Rufus Giwa Polytechnic Owo and Adeyemi College of Education, Ondo. The reason being that that these institutions have similar characteristics in terms of challenges, governance, management, administration and un-debatable unprecedented development.

\section{Funding Challenges of Tertiary Institutions in Nigeria}

Government may not be able to fund tertiary education effectively and efficiently due to in-accurate statistics to 
plan, prevalent economic situation in Nigeria and embezzlement and an incredible rate of corruption of some unpatriotic past leaders (both military and civilian). In this regard government and some of the other stakeholders have been exploiting avenues for funding tertiary education.

Ogbogu (2011) asserted that government is the major source of funds for federal universities in Nigeria. It provides $90 \%$ of the total income disbursed through the Nigeria Universities Commission (an organization that assists government in co-ordinating the affairs of the universities). The remaining $10 \%$ is locally generated by each university and other tertiary institutions

World Bank (1994) stated in its report on Nigeria tertiary institutions that the equipment for teaching, research and learning are either lacking or inadequate and in a bad shape to permit the institutions the freedom to carry out academic functions. With the same zeal, Ogbogu (2011) opined that it is worrisome to note that Nigeria tertiary institutions are fast decaying in terms of required resources production, process lecture halls, laboratories, students' hostels, library space, books, journals and office spaces are seriously inadequate. Moreover, even government visitation panels which investigated the operations of all federal universities between 1999 and 2003 reported that physical facilities in the universities were in deplorable conditions (NCE 2011). Oyeneye (2006) observed that in the past, education in Nigeria was very qualitative and enviable due to high standard, hence graduates of Nigerian institutions were unhesitatingly admitted to high profile institutions in the United States of America and the United Kingdom. Same cannot be said of the current states of tertiary education in Nigeria. Most of the universities are only enjoying their past but, now, fading glories of their names. The condition of resource inadequacy is what Ajayi and Ayodele (2004) described as an off-short of the endemic financial crisis in the sector. Scholars such as Adegbite (2007) Eisemon and Vavis (2001) have identified the factors responsible for the under-funding to include the structural adjustment programme (SAP) lack of adequate planning, proliferation of tertiary institutions, and ah-hoc expansion of enrolment academic and nonacademic employment ratio.

Tertiary institutions in the country have consistently inadequate resources which invariably have affected the quality of output produced. Under-funding of education, more so at tertiary education levels, has become a recurring phenomenon in the policy as almost everybody seems to agree that funds allocation to the sector cannot meet the needs in view of the monumental decadence in the education sector (Ezekwesili, 2006). Yet, stakeholders in the sector appear not to understand how to formulate a lasting policy to the problem of funding tertiary institutions which has led to increasing decline in the quality of education in Nigeria. The proportion of total expenditure devoted to education has been on the increase, but, this has been grossly inadequate considering the phenomenal increase in students' enrolment and increasing cost, aggravated by inflation. As a result of this, the quality of teaching and learning has fallen considerably for lack of adequate teaching and research materials coupled with over-crowded, un-conducive teaching and learning environment.

\section{The Achievements of Education Trust Fund (ETF) on Nigeria Higher Institution}

According to the ETF (2009), the following specific achievements have been recorded by the fund:

1) Restructuring of the administrative machinery of the fund through employment of competent staff which has resulted to greater efficiency in tax collection, effective project monitoring and increased fund generation.

2) Computerisation of ETF/ FIR Desks in 16 Area Tax offices of the FIRS with the highest education tax revenue yield.

3) Intervention in critical areas in the education sector thereby leading to improvement in academic infrastructure nationwide. The intervention has taken the forms of creating awareness in information and communication technologies (ICT), introduction of Net-Nigeria project in collaboration with school Net- Africa, playing the role of a partner for the take-off of the open and Distance learning and the National virtual Library projects, intervention assistance for the education of the handicapped.

4) Significant increase in ETF collection profiles from N5 billion in 1999 to N8 billion in 2000 to N16 billion in 2001 and greater increases ever after.

5) Allocation/Disbursement to institutions including centres of excellence in the six geographical zones in the country tertiary institutions in: The South-West zone, South-East zone, South-South zone, North-East zone North-Central zone and the North -West zone

\section{Methodology}

The Research design used in this study is a descriptive research of the survey type. The survey was used to examine a large proportion of the population.

\subsection{Population}

The population of the research comprised all tertiary institutions in Ondo state, Nigeria. 


\subsection{Sample and Sampling Techniques}

Four Tertiary institutions were randomly selected for the study. The total of 200 copies of questionnaire were distributed and 50 copies were allocated to each institution. In each institution, the 50 questionnaire copies were divided among students, teaching and non teaching staff.

\section{Analysis of Research Question}

Research Question 1: How does Education Trust Fund contribute to the development of higher education system in Nigeria?

The impact of Education Trust Fund contribution to tertiary institutions in Nigeria is encouraging?

\begin{tabular}{|l|l|l|l|l|}
\hline & Frequency & Percent & Valid Percent & Cumulative Percent \\
\hline SD & 3 & 1.5 & 1.5 & 1.5 \\
D & 37 & 18.4 & 18.8 & 20.3 \\
Valid A & 67 & 33.3 & 34.0 & \\
SA & 90 & 44.8 & & 54.3 \\
Total & 197 & 98.0 & 45.7 & \\
888 & 3 & 1.5 & & \\
Missing System & - & - & & 100.0 \\
Total & 3 & 1.5 & & \\
& 200 & 100.0 & 100.0 & \\
\hline
\end{tabular}

Researcher's Survey, 2018

Table 1 indicates that out of 197 staff and students that were sampled by the researcher, $44.8 \%$ and $33.3 \%$ choose strongly Agreed and Agreed respectively. This therefore implies that the impact of Education Trust Fund contributions to tertiary institution in Nigeria is encouraging. The finding is confirmed by the mean size of 3.24 as against the 2.50 decision rule.

Research Question 2: Is Education Trust Fund a major source of fund to Nigerian tertiary institutions?

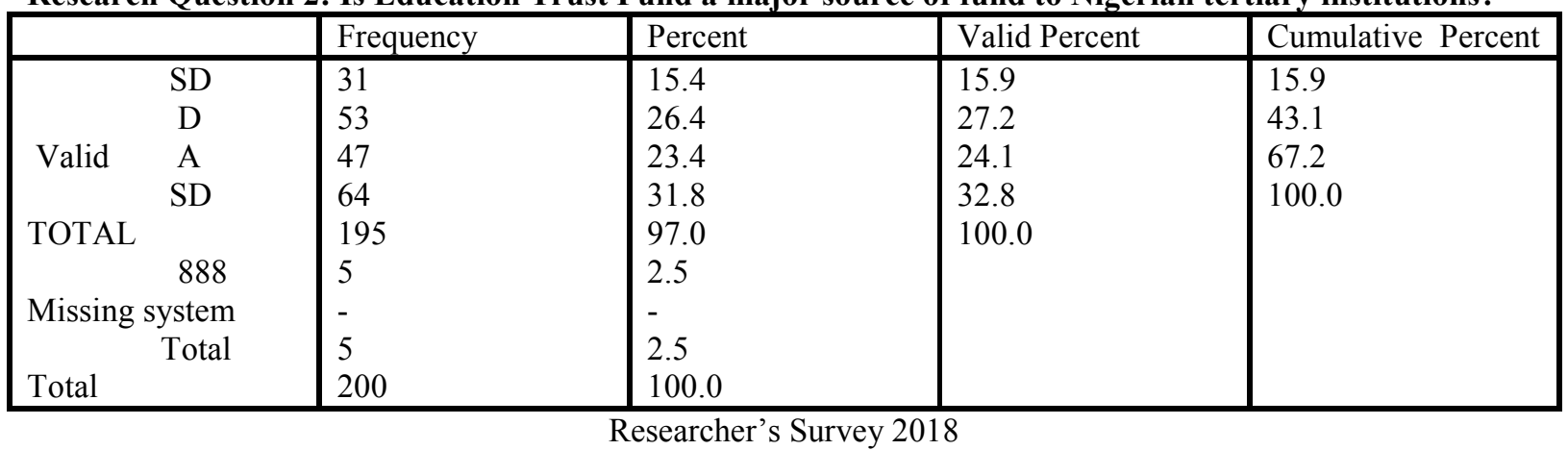

Table 2 indicates that out of 195 staff and students that were sampled by the researcher, $31.8 \%$ and $23.4 \%$ choose strongly Agreed and Agreed respectively. This thus implies that the Education Trust Fund is a major source of fund to tertiary institutions in Nigeria. The finding is further confirmed by the mean size of 2.74 as against the 2.50 decision rule

Research Question 3: Does Education Trust Fund provide facilities and infrastructures to tertiary institutions?

\begin{tabular}{|c|l|l|l|l|}
\hline & Frequency & Percent & Valid Percent & Cumulative Percent \\
\hline SD & 4 & 2.0 & 2.0 & 2.0 \\
D & 15 & 7.5 & 7.6 & 9.6 \\
Valid & 97 & 48.3 & 49.2 & 58.9 \\
SA & 81 & 40.3 & 41.1 & 100.0 \\
888 & 197 & 98.0 & 100.0 & \\
Missing System & 3 & 1.5 & & \\
Total & - & - & & \\
Total & 3 & 1.5 & & \\
\hline
\end{tabular}

Researcher's Survey 2018

Table 3 indicates that out of 197 staff and students that were sampled by the researcher, $40.3 \%$ and $48.3 \%$ choose Strongly Agreed and Agreed respectively. This therefore implies that the Education Trust Fund provides facilities and infrastructures to tertiary institutions in Ondo state. This is further confirmed by the mean size of 3.29 as against the 2.50 decision rule. 
Research Question 4: Is impact of Education Trust Fund felt much in tertiary institutions in Nigeria?

\begin{tabular}{|c|l|l|l|l|}
\hline & Frequency & Percent & Valid Percent & Cumulative Percent \\
\hline SD & 36 & 17.9 & 18.4 & 18.4 \\
D & 69 & 34.3 & 35.2 & 53.6 \\
Valid A & 45 & 22.4 & 23.0 & 76.5 \\
SA & 46 & 22.9 & 23.5 & 100.0 \\
Total & 196 & 97.5 & 100.0 & \\
888 & 4 & 2.0 & & \\
Missing System & - & - & \\
Total & 4 & 2.0 & & \\
Total & 200 & 100 & \\
\hline
\end{tabular}

Table 4 shows that out of 196 staff and students that were sampled by the researcher, $22.9 \%$ and $22.4 \%$ choose Strongly Agreed and Agreed respectively. This finding implies that the impact of Education Trust Fund is much felt in Nigeria tertiary institutions. This is further revealed by the mean size of 2.52 which is slightly above the 2.50 decision rule.

Research Question 5: Does Education Trust Fund give students in your tertiary institution scholarships?

\begin{tabular}{|c|l|l|l|l|}
\hline & Frequency & Percent & Valid Percent & Cumulative Percent \\
\hline SD & 39 & 19.4 & 20.2 & 20.2 \\
Valid A & 54 & 26.9 & 28.0 & 48.2 \\
SA & 57 & 28.4 & 29.5 & 77.7 \\
Total & 43 & 21.4 & 22.3 & 100.0 \\
888 & 193 & 96.0 & 100.0 & \\
Missing System & 6 & 3.0 & & \\
Total & 1 & 0.5 & & \\
Total & 7 & 3.5 & & \\
\hline
\end{tabular}

Table 6 indicates that out of 200 staff and students that were sampled by the researcher for the study, 28.4\% and $21.4 \%$ choose Strongly Agreed and Agreed respectively. This findings indicates that the Education Trust Fund gives scholarships to students in tertiary institutions in Ondo State. This is also confirmed by the mean size of 2.54 as against the 2.50 decision rule.

Research Question 6: Does Education Trust Fund encourage staff training in schools?

\begin{tabular}{|c|l|l|l|l|}
\hline & Frequency & Percent & Valid Percent & Cumulative Percent \\
\hline SD & 11 & 5.5 & 5.7 & 5.7 \\
Valid A & 64 & 31.8 & 33.0 & 38.7 \\
SA & 47 & 23.4 & 24.2 & 62.9 \\
Total & 72 & 35.8 & 37.1 & 100.0 \\
888 & 194 & 96.5 & 100.0 & \\
Missing System & 6 & 3.0 & & \\
Total & - & - & & \\
Total & 6 & 3.0 & & \\
\hline
\end{tabular}

Researcher's Survey 2018

Table 6 shows that 194 respondents which represent 35.8\% and 23.4\% choose Strongly Agreed and Agreed respectively. This implies that the Education Trust Fund encourages staff training in tertiary institutions in Ondo state. The findings is further confirmed by the mean size of 2.93 as against the 2.50 decision rule. 
Research Question 7: There is no single physical project of Education Trust Fund in my school since its creation?

\begin{tabular}{|c|l|l|l|l|}
\hline & Frequency & Percent & Valid Percent & Cumulative Percent \\
\hline \multirow{4}{*}{ SD } & 99 & 49.3 & 50.3 & 50.3 \\
D & 68 & 33.8 & 34.5 & 84.8 \\
A & 18 & 9.0 & 9.1 & 93.9 \\
SA & 12 & 6.0 & 6.1 & 100.0 \\
Total & 197 & 98.0 & 100.0 & \\
888 & 3 & 1.5 & & \\
Missing System & - & - & & \\
Total & 3 & 1.5 & & \\
& 200 & 100.0 & & \\
\hline
\end{tabular}

Researcher's Survey 2018

Table 5 indicates that out of 197 staff and students that were sampled by the researcher for the study, $6.0 \%$ and $9.0 \%$ choose Strongly Agreed and Agreed respectively. This therefore implies that the tertiary institutions in Ondo State have physical projects built by Education Trust Fund. The finding is further confirmed by the mean size of 1.71 , which is significantly below 2.50 decision rules.

\section{Discussion}

The greatest challenge facing education trust fund appears to be the very low capacity utilization of the fund. Huge sums of money in the fund remain un-accessed by the beneficiaries. However, based on this finding, it was revealed that the Educational Trust Fund (ETF) has no problem in discharging its duty in tertiary institutions in Ondo State. It is observed that out of 199 respondents $34.8 \%$ and $30.8 \%$ 'Strongly agreed' with the fact that there is enough space to accommodate ETF projects in state public tertiary institutions. The findings show that government is in full support of the project as the highest percentage of the respondents were in agreement with the project. The funds been allocated for the project are equally judiciously used. Funds, as revealed in this study, are equally made available and used for ETF Projects in all the public tertiary institutions in Ondo State.

\section{The Achievements of Education Trust Fund Towards their Stated Objectives}

The results obtained show that the ETF project in the state is moving towards achieving its goals in the tertiary institutions in the state. That is, (championing of scientific and information literacy, awarding of scholarships, training of personnel, making adequate provision of infrastructural facilities which include the following: building of hostel, building of health centres, lecture theatre, construction of relaxation/recreation centres and building of offices.) This was in support of Ugwoke (2011) "who postulated that education fund has erected so many structures in Nigeria tertiary institution". This also go in line with the result of this study which shows that out of 196 staff and students sampled, $28.4 \%$ and $27.4 \%$ were of the supportive opinion that it champion informative literacy, similarly, out of 193 respondents, $21.4 \%$ and $28.4 \%$ were also of the opinion that it gives scholarship to the students. More so, the highest percentage of the respondents, $35.8 \%$ and $23.4 \%$ choose Strongly Agreed and Agreed respectively. This implies that the Education Trust Fund encourages staff training in tertiary institutions in Ondo state. Lastly, it indicates that out of 197 staff and students that were sampled by the researcher, $46.8 \%$ and $37.8 \%$ choose Agreed and Agreed respectively. This therefore implies that tertiary institutions in Ondo state benefit from Education Trust Fund Intervention fund.

\section{Conclusion}

It is evident that TETFUND has performed meritoriously as far as Education is concerned in Nigeria. However, in the area of monitoring of funds released to beneficiaries, government should make sure that reliable and unbiased people are in charge, and the money so released, should be used for what it is supposed, as government agents ensure fast-tracking implementation.

\section{Recommendations}

Despite the educational trust fund intervention, Nigeria still lacks necessary funds to upgrade the institutions to international standard. This emanates from the fact that tertiary education is cost effective. Again, the funds approved by the educational trust fund are not always accessed by the beneficiary of tertiary institutions.

Based on these facts, the following recommendations are made:

$>\quad$ To make it easier for tertiary institutions to access the approved education trust fund, it is expedient to reduce or remove the bureaucratic bottle-necks associated with accessing such approved funds.

Projects by educational trust fund should be awarded to honest, competent and certified contractors .The delays in contract execution should be removed, to avoid the negative effects of variation which usually come in form of contract terms on the easy excuse of market price fluctuation This brings a great delay in 
project completion.

$>\quad$ There should be a sincere monitoring-team that will help in enhancing adequate disbursement of Educational Trust Fund (ETF) to the appropriate purse. Relevant stakeholders should be encouraged to contribute more towards educational development in our tertiary institutions in varying degrees.

$>\quad$ Educational trust fund should improve transparency and accountability by the fund managers on the beneficiaries, rigorous training and the re-training of the staff of the fund in tax audit and effective monitoring of project implementation should be more vigorous.

Funds raised for education trust fund should be used for the purpose for which it was raised and not for political campaign, politicians' salaries, uncharitable and unpatriotic spending not far from embezzlement.

\section{References}

Adegbite J.G.O. (2007) "The Education Reform Agenda: challenges for Tertiary Education Administration in Nigeria" being a paper presented at the sixth annual seminar of the conference of Registrars of Colleges of Education in Nigeria (South West Zone) at the College of Education, Ikere -Ekiti, Ekiti State.

Adeyemi, K and Osunde, A. (2005) "An assessment of the academic achievement of students in two modes of part-time programme in Nigeria" The International Review of Research in Open and Distance Learning 6(2), 23-31.

Ahmed, M (2011) "Universities Infrastructure and Services" Concession Options Consideration and Methodologies Retrieved from wwwunilorin.edu.ng/.../ Ahmed UNIVERSITY 2\%Infrastructure... ( Accessed on August 10 (2011).

Ajayi I.A. and J.B Ayodele, (2002) 'Fundamentals of Education Management' Green Line Publishers, AdoEkiti.

Adesanya, O. O.(2007)'’Financing tertiary education in Nigeria'’ Int. Afr. Am. Study 6 (!)

Bamiro, O, A. and O. S. Adedeji ( 2010) " Sustainable Financing of Tertiary Education in Nigeria " Ibadan University Press, Ibadan.

Eisemon, T.O. and C. H. Davis (1990) 'Strengthening University Research and Training Capacities in SubSaharan Unpublished Manuscript.

Ezekwesili, O.(2006)' 'Lack of fund is the bane of the Nigerian education System (9' clock NTA Network News October, 2006.

Ochuba, V.O (2011) Strategies for Improving the Quality of Education in Nigerian Universities.

Oduleye, S.O.(1985) Decline in Nigerian Universities Tertiary Education', 14:17-40.

Oyeneye, O. Y (2006) 'Current Issues in the Administration of University Education in Nigeria'. Lecture delivered at the $15^{\text {th }}$ convocation ceremony of University of Ado-Ekiti, Nigeria on March,29.

Ogbogu, A. C. (2011)'’Modes of Funding Nigerian Universities and the Implication on Performances A paper presented at the 2011 Barcellon European Academic Conference, Spain.

Utulu , C. C (2002) Quality of University Education in Nigeria : Problems and Solutions. Common wealth Council Education. Admin. Management 29 (1). 